\title{
Perceiving Shit as Shit: On the Grammar of Patriarchy in Solanas' SCUM Manifesto
}

\author{
Salla Peltonen ${ }^{1 *}$, Mio Lindman ${ }^{2}$, Sara Nyman ${ }^{3}$
}

Published: October 30, 2017

\begin{abstract}
This article investigates the ways in which Valerie Solanas takes on what we call the 'grammar of patriarchy' in The SCUM manifesto. We argue that the manifesto provides us with philosophical insights similar to those provided by thinkers such as Nietzsche, Butler, Adorno and De Beauvoir. We argue that the philosophical and critical value in the manifesto lies in Solanas' descriptions and her style of writing. In the manifesto, as well as in this article, conventions of philosophical writing, and feminist academic writing are challenged. By reading the manifesto as a philosophical text, the article focuses on questions of human life, death, hope, change, frustration, anger and love.
\end{abstract}

Keywords: Solanas, SCUM Manifesto, philosophy, critique, description

"The effect of fathers, in sum, has been to corrode the world with maleness. The male has a negative Midas Touch - everything he touches turns to shit" (Solanas 2004: 45).

\section{ENCOUNTERING THE SCUM MANIFESTO}

We first read Solanas during our undergraduate years. Solanas spoke to us in a way no philosopher or feminist writer had previously. Reading The SCUM Manifesto ${ }^{1}$ was almost like a conversion experience. We arranged reading groups and wanted everybody to read it. The text should be part of the curriculum, we thought, and we demanded a course in feminist philosophy, the first one to be held at our department. For us The SCUM Manifesto had the originality of a classic. It combined philosophy, politics, and ethics. Utopian in its content, although deeply embedded in the experiences of everyday life, the manifesto was an example of hardcore politics, anger, vision, judgment - but also philosophy.

Thinking with Solanas became a necessity in the philosophical environment of our undergraduate years, where we experienced a clash with both academia and philosophy. Not because of the content of philosophy (although sometimes that too; we learned how intertwined racism and sexism are with the philosophical canon), but because

\footnotetext{
${ }^{1}$ Valerie Solanas wrote The Scum Manifesto and started distributing the text in 1967 by selling it in New York City, charging ' $\$ 2$ for men and only $\$ 1$ for women' (Inkiel quoted in Fahs 2008: 606). The text has been published in several versions over the years, first in 1986 by Olympia Press. For an overview of the different versions see Fahs (2008: 606). In this article we use the 2004 version published by Verso, with an introduction by Avital Ronell. One version goes under the title 'S.C.U.M. Manifesto' as the acronym for 'society for cutting up men'. This version is still in circulation and appears, for example, in Sara Stridsberg's and Tiina Rosenberg's work on Solanas, although Solanas apparently never herself intended this acronym, but rather meant the title 'SCUM' to be read as 'scum' (Fahs 2008: 607; Rowe 2013: 79). Breanne Fahs writes that the version edited by Solanas' publisher Maurice Giordias was 'used to sell more books but never endorsed by Solanas' (Heller quoted in Fahs 2016: 261). Apparently, it was also Giordias who was originally the intended target the day when Solanas shot Andy Warhol, Mario Amaya and Fred Hughes. Solanas also borrowed a copy of the S.C.U.M. Manifesto from the New York Library and rewrote the title on the book and stated that S.C.U.M. Manifesto is based on The SCUM Manifesto by Valerie Solanas. She also wrote 'Lie! Fraud! Never, never!' to indicate her dissatisfaction with the text (see Fahs 2008; 604, Rowe 2014).
}

${ }^{1}$ PhD Student, Gender Studies at Ábo Akademi University, FINLAND

${ }_{2} \mathrm{PhD}$ (philosophy), Freelance writer whose research interests range from work/labour, to feminism and moral philosophy, FINLAND

${ }^{3} B A$ (philosophy), Freelance Writer, FINLAND

*Corresponding Author: speltone@abo.fi 
of the highly masculine, patriarchal and sometimes outright sexist environment we found ourselves in. We were eager to study; we read the classics and we read feminist theory, trying to make sense of our situation. Engaging with both the traditional texts of the philosophical canon as well as the classics of feminist theory - another kind of canon - changed our perspectives and our lives. We were challenged intellectually but we also experienced, as many before us, what it meant to be young, loud and what it meant not to count as one of the guys in a traditional and strongly masculine academic environment. We were taking on philosophy.

The philosophers at the department did not recognise Solanas as philosophically relevant, and we were told that her text was a political manifesto, and not to be taken seriously as philosophical writing. Obviously, this was a text written by a lunatic; 'wasn't she the one who shot Andy Warhol?' was a common reaction (see also Fahs 2008: 591, Rowe 2013: 75). The SCUM Manifesto was, as it often is, seen as an example of madness and radical feminism, a tradition that was understood as problematic as such. ${ }^{2}$ The Manifesto is often cited as one of the primary examples of the radical feminism of the 1960s and 70s, although Solanas herself never claimed to be a feminist and clearly distanced herself from all forms of identity politics. As students of Philosophy, we were told that we should know that philosophy has nothing to do with politics. Over the years, we have experienced frustration in trying to talk about gender, sexuality and power to philosophers and have been brushed off with slippery jokes and insinuations. Over ten years have passed since our initial encounter with The SCUM Manifesto, and we still keep on shouting, and writing, about Solanas. ${ }^{3}$

\section{READING SOLANAS AS A PHILOSOPHER}

In what follows we read Solanas as a philosopher and The SCUM Manifesto as a philosophical text. We argue that Solanas provides us with philosophical insights, similar to those of thinkers such as Nietzsche, Butler, Adorno and de Beauvoir. Inspired by the philosophy of Ludwig Wittgenstein (1997) and his concept of grammar and his philosophical 'method' of description, we investigate the ways in which Solanas takes on the 'grammar of patriarchy' through her writing, style and voice. We are not advancing an argument or a thesis about the Manifesto, as much as approaching the text by asking what philosophical relevance it can have and how it can subvert our habitual ideas of what 'the philosophical' amounts to. Solanas' manifesto, we claim, has critical value in that it roots its critique not in abstract, intellectual realms, in a theory about language, meaning or power, for example, but in the everyday: in ordinary language and in our shared human lives. Solanas draws connections between questions that can be made intelligible by presenting us with what can be described as a moral perspective; one that focuses on human life, death, hope, change, frustration, anger and love.

We explore what Solanas can teach us about the struggles of understanding a culture built around identity, violence and contempt. Solanas' text takes the form of a wound, a call for change, the lone voice crying in the wilderness that, paradoxically, reminds us of our shared life. Solanas speaks from the margins - and we suggest this position should be treated as a philosophical point of view; that is, we can learn something from her wounded, raw descriptions of a patriarchal form of life. The manifesto provides us with the kind of critique that does not distance us from reality, but rather rubs our faces right in what hurts and damages us. We elaborate on - sometimes using the anecdotal - the kind of existential attitude Solanas' Manifesto expresses. This attitude is connected to the struggles of understanding and to no more and no less than the daily struggle of living. In other words: we claim that the philosophical value of the text lies in how it deals with reality, and with what is real. SCUM Manifesto is a challenging and difficult text to read because of its style, its words and its affects. It teases out our gut reactions. This cannot be isolated from how we write. Rather than the traditional, cool and distant academic style of conspicuously presenting the argument - as we said, we have none - we do not try to hide in which ways we are moved, sometimes unsettled, by Solanas' perspective.

'Grammar of patriarchy' is what we call Solanas' brutal descriptions of violence, contempt and self-absorption as deeply ingrained elements in our form of life. In the manifesto, we get to see a culture of boredom and hate Solanas pinpoints the kinds of power structures and psychology that transform this culture into what it itself views as the most advanced form of life in the world. Solanas describes an existence or a form of life dominated by 'Big Daddy' who has a Midas Touch and who turns everything into shit. 'Daddy's girls' are the women in this world,

\footnotetext{
${ }^{2}$ Solanas herself is a queer figure in many senses of the term. For an overview of Solanas as a writer and in particular of The Scum Manifesto, see Rowe 2011; Fahs 2008, 2016; Ronell 2004, 2010; and McBean 2016. For a biography over Solanas, see Fahs 2014.

${ }^{3}$ As Avital Ronell aptly notes: "If you are pegged as a woman your scream might be noted as part of an ensemble of subaltern feints - the complaint, the nagging, the picking, the chatter, the nonsense by which women's speech has been largely depreciated or historically tagged.” (2004: 3-4).
} 
who appraise 'Daddy, and thereafter, other men' and who accept themselves as inferior (Solanas 2004: 44). But Solanas also announces the (potential) existence of SCUM, fuck-up crews and groovy thrill-seeking females 4 .

The conflict, therefore, is not between females and males, but between SCUM - dominant, secure, selfconfident, nasty, violent, selfish, independent, proud, thrill-seeking, free-wheeling, arrogant females, who consider themselves fit to rule the universe, who have free-wheeled to the limits of this 'society' and are ready to wheel on to something far beyond what it has to offer $[\ldots]$, and nice, passive, accepting 'cultivated', polite, dignified, subdued, dependent, scared, mindless, insecure, approval-seeking Daddy's Girls (Solanas 2004: 70).

The SCUM Manifesto can be read as a kind of cultural critique. When Solanas here speaks of Daddy's Girls and females and males, she is speaking of different perspectives we can have on life, of different cultural forms of belonging and ways of living, relating and to occupying public space. This is the way in which she reveals collective forms of identity, as gendered identities are bogged down in patriarchal relations. Solanas thus confronts us with the question of how gendered identities come between people. Solanas' SCUM marks a change in perspective, it is a description of a form of life that is not dead and does not seek to emulate corrupted gendered ways of living.

The SCUM manifesto actualises what Rita Felski (2015) aptly describes as the moods and modes of critique, but in a slightly different way than the tradition of critical theory that has dominated academic critique over the last decades. Felski describes how the hermeneutics of suspicion, the emphasis on subversion, irony and revealing the workings of ideology have presided in critical scholarship (see also Moi 2017). It would be tempting to read Solanas in this critical mode (asking what the text reveals, what it hides; to engage in a 'deconstructive' mode of reading), but in this article, we want to avoid and criticise this kind of reading as a precisely the kind of 'epistemic habit' that Felski and others have diagnosed. ${ }^{5}$ We claim that the text has critical, political and philosophical value, and that it hits at the core of the particular difficulties of judgment that feminist, queer and postcolonial critiques face and problematise. The manifesto brings out the logic and irrationality of a culture that understands gender as Identity, as fundamental to our being. But Solanas does not put her faith in 'men' or 'women'. For her, Man is dead. In her own way, Solanas challenges the idea and the collectivity that comes with identification and identity ${ }^{6}$. This perspective can be described as a kind of 'anti-normative' thinking. As Avital Ronell notes, Solanas was a kind of queer thinker long before queer theory existed (Ronell 2004: 17).

\section{CONTEXTUALISING SOLANAS AND THE SCUM MANIFESTO}

Most of the discussions of the manifesto focus in one way or another on Valerie Solanas as a person. Descriptions of her as a lunatic or radical feminist or man-hating lesbian are often intermingled with a suspicion toward taking anything written by a woman like that seriously (Rowe 2009). The manifesto and the figure of Valerie Solanas have both been hailed as the future of feminism and dismissed as an oxymoron in the history of feminism. Several writers have linked Solanas to second wave feminism and to the history of radical feminism (cf. Third 2006). In recent years, Solanas has become somewhat of an iconic figure for feminism (McBean 2016). The text itself has been read as carnivalesque, satire, irony, subversive and as nihilist and anarchist (cf. Fahs 2008, Haut 2007). When the manifesto is read as a critical text, it is read as satirical or utopian, and less so as critique to be taken seriously as critique. Although the commentary around the manifesto has been attentive to the insightful conceptual remarks and claims Solanas makes about patriarchy, violence, and gender, the text is rarely read in the context of philosophy or as having philosophical value.

Avital Ronell $(2004,2010)$ as a reader of the manifesto is an exception. Ronell discusses Solanas primarily as a writer but situates her in the philosophical canon by comparing her to the likes of Nietzsche, Goethe, Marx Freud, Derrida, Butler, and Deleuze, stating that "Valerie Solanas runs with the best of them" (Ronell 2004: 7). The common denominator is a critical distance to patriarchal patterns, thoughts and figures: the father figure, paternity as fiction and understanding gender as performative, and most importantly, as a cry for 'The Ends of Man' (Ronell 2004: 5). Ronell situating Solanas in this crowd, captures quite well some of the main aspects of Solanas' critique. Ronell acknowledges the historical surrounding of The Scum Manifesto, but the historicising gesture functions like an invitation for the reader to engage with the text as a part of a particular archive of thought, not as a gesture that

\footnotetext{
${ }^{4}$ Here it is important to note that SCUM for Solanas denotes an attitude, or a perspective, and functions as a metaphor for an alternative to destruction. The way SCUM presents us with a vision of an alternative has somewhat been overshadowed by the circulation of the S.C.U.M Manifesto, titled by Giordias.

${ }^{5}$ Cf. Heather Love (2014), Toril Moi (2009, 2017), Amanda Anderson (2009), Felski \& Anker (2017).

${ }^{6}$ Here collectivity is understood as collective forms of identification, or collective forms of thinking, similarly to the ways in which Heidegger writes about Das Man, or Nietzsche about collective forms of 'morality'; and thus, we do not have in mind forms of resistance or political struggle when we talk about collectivity.
} 
merely provides a 'setting', in which to put Solanas and her manifesto. She reads Solanas as a commentator, a critical thinker. However, she also describes her as 'a psycho', 'butch-dykey angry, poor, and fucked up' (Ronell 2004: 17). Solanas was all of the above, an icon, a thinker, a rebel. In our reading we are inspired by Ronell's approach in thinking about how we can read the manifesto as a philosophical text that simultaneously is a critique of a particular life form.

Although aware of the troublesome aspect of contextualising Solanas within the domain of philosophy - a tradition she herself gives the finger to - we claim that there is philosophical value in the text that goes beyond the domains of academic philosophy and feminism. Solanas is certainly an odd figure in the genealogies of feminism, and it is important to note here that in our reading of The SCUM Manifesto and Solanas, the idea is not to situate her within an intellectual legacy, legitimise her, pin her down or define her as belonging to a specific canon. The desire to do so is in itself a symptom, one could say, of the kind of culture Solanas so strongly distances herself from (collectivity, decency, academic quasi-activity). To sum up: Our viewing the manifesto as a philosophical text has nothing to do with domesticating it, or making it less dangerous. As we want to show, the opposite, rather, is the case.

\section{NO ARGUMENTS (DESCRIPTION)}

Life in this society, at best, an utter bore and no aspect of society being at all relevant to women, there remains to civic-minded, responsible, thrill-seeking females only to overthrow the government, eliminate the money system, institute complete automation and destroy the male sex (Solanas 2004: 35).

These are the opening words of The SCUM Manifesto. These words are of great importance in understanding the spirit of Solanas' work, and, we argue, understanding the spirit of her work might give us a deeper understanding of the questions feminists struggle with today. We emphasise spirit here as a way of capturing the way in which Solanas' Manifesto is not a theoretical text; she doesn't have a thesis and she doesn't argue. There are no positions to be defended in her texts - she provides her readers with a perspective. The power of her critique lies in her descriptions. ${ }^{7}$ Solanas' philosophical method, as it were, is descriptive and diagnostic; this is where its philosophical remarks can be seen. She doesn't need another language, theory or a thesis to think through. Her thinking appears in the descriptions she offers. She trusts the reader and she trusts language. She trusts us to know what concepts, such as 'contempt' and 'love' mean'. In her writing the moral meaning that concepts have in our lives becomes evident, and she shows this without needing to historicise, and without needing to provide a genealogy of for example 'love' or 'the family'. This is a crucial point. Although we can 'explain' the different ways in which historical and societal categories and concepts gain their meaning through historicising them, we are still left with the question of how to understand the challenges that they pose as political, moral and philosophical questions in our lives.

Solanas reminds us of how moral impulses and reactions like anger and despair have spurred feminist questions, critique and actions. These are concepts that in a sense provide theoretical discussions with their intelligibility, as they form the background of feminist thinking. One could say that feminist thinking is internally related to anger, despair, hope and love. This is the feminism we pledge our allegiance to, a feminism that doesn't find its feet in this world and therefore demands change, new worlds. As Avital Ronell writes in Fighting Theory: "Anger is in some sense the site of thought. One can be in states other than anger, but if there is no anger I don't see how one can think" (Ronell 2010: 25). In this text we direct our anger at what we call the 'grammar of patriarchy'.

\section{GRAMMAR AS A FORM OF UNDERSTANDING}

By 'grammar' we mean the kind of sense-making that patriarchy contains; what makes sense if one approaches life from a particular angle - when humanity is divided into the (damaging) dynamics of 'men' and 'women', to be

\footnotetext{
${ }^{7}$ Description is a central aspect of Ludwig Wittgenstein's philosophical method (1997) that focuses our attention on language use. Here we are inspired by Wittgenstein's descriptive method but also follow the work of Heather Love (2014) and Toril Moi (2017) in emphasising descriptions as the ways in which a literary text can reveal its philosophical and theoretical value. Description has for long been discarded as unanalytical against interpretation and analysis, and as such, seen as useless for scholarly work. Recently, description has gained some attraction, mainly in literary studies, as a means of approaching texts and as a way of reading (see Love, Best and Marcus 2016).

${ }^{8}$ This is what makes SCUM Manifesto a philosophical rather than academic text, and where we diverge from the 'epistemic habit' of understanding language as primarily performative (Sedgwick 2003), or of concepts being primarily in need of genealogical (Foucault) and deconstructive (Derrida) modes of analysis but rather emphasise a Wittgensteinian approach to language and meaning.
} 
more specific. 'Grammar', then, is our clear-sighted descriptions of the patterns in how we talk, how we think, how we judge, how we feel. To allude to Wittgenstein: to attend to how we actually talk is also to attend clearsightedly to how we live. The challenge is to 'look and see' (Wittgenstein 1997, \ 66). 'Grammar' is thus not a fixed structure, and is not to be understood in a purely linguistic sense. Solanas' approach reminds us of Wittgenstein's philosophy, in which language use and descriptions of our language use are the way to gaining clarity when a philosophical problem is bothering us. Wittgenstein's emphasis on descriptions (and grammar) is based on a critique of ways in which philosophers have a tendency to offer general theories, overlooking particular cases and examples in their search for theses about reality, knowledge, being or identity. The emphasis on description and language use reflects Wittgenstein's understanding of philosophy as therapeutic. He writes:

And we may not advance any kind of theory. There must not be anything hypothetical in our considerations. We must do away with all explanation, and description alone must take its place. And this description gets its light, that is to say its purpose, from the philosophical problems. These are, of course, not empirical problems; they are solved, rather, by looking into the workings of our language, and that in such a way as to make us recognize those workings: in despite of an urge to misunderstand them (Wittgenstein \$109, 1953/2009: p. 47).

Wittgenstein's emphasis on description is useful in reading The SCUM Manifesto, where we find descriptions that reveal forms of understanding and perspectives on the world: descriptions of the good family girl, the active male or the sissy. Taking Wittgenstein's point further, one could say that in reading Solanas, the challenge is to see what these descriptions can $d o$ - what they tell us. Then we return to the level of impulses, reactions and judgment: we have to let the descriptions work on us. Descriptions of course are never neutral, and in the case of The SCUM Manifesto they express in several ways what it means to be an 'embodied and embedded subject', to paraphrase Rosi Braidotti, or what it means to speak a 'politics of location', to paraphrase Adrienne Rich.

\section{DESCRIBING AND FACING REALITY}

\section{So what kind of work do descriptions do?}

One could say that Solanas portrays the kind of difficulty that Cora Diamond (2008) writes about in her essay The Difficulty of Reality and the Difficulty of Philosophy, but in a very different spirit. ${ }^{9}$ Diamond's essay is about the ways we struggle to find words when faced with aspects of reality that we find incomprehensible. Diamond shows how real-life questions and problems are distorted when they are abstractly reflected upon. One of Diamond's examples in making this argument is a reading of J. M. Coetzee's novel Elizabeth Costello, in which the protagonist is a woman whom Diamond describes as 'haunted by the horror of what we do to animals' (Diamond 2008: 46). Costello is haunted, but also very lonely in seeing what she sees and in experiencing reality as an outrage. The point is she can't come to terms with what she sees around her - the killing and the slaughtering and eating of animals, this mostly ordinary thing we do. Diamond is critical of the idea that our moral existential questions and concerns could be settled through philosophical argumentation, feminist theory, or moral philosophy providing a kind of independent neutral logic that could dictate the meaning things will or should have for us. Rather, she wants to point out, (as we do in our reading of the manifesto) moral meaning is not rooted in theories about what is right or wrong, or questions of how one should live ('is it right to eat meat?'). Such questions and concerns 'are born out of morality [...] born out of the things that matter between us: how we can show love, or pity, or concern, and how we can fail or harm one another' (Nordling 2013: 19, emphasis in original). When reading Solanas' manifesto in this light, one can say that it reveals the roots of feminist critique and criticism, the roots of morality, affects and politics - not only as embedded in our existence and shared lives, but also the ways in which they can all be corrupted.

\footnotetext{
${ }_{9}^{9}$ Diamond's essay concerns ways in which moral and ethical concerns are rooted in our shared, everyday lives and cannot be 'settled' or decided in an abstract, theoretical realm. The essay underlines the fact that the moral philosophical questions often take the form of 'what would you do', or 'what do you think', where the difficulty is precisely in figuring out what one thinks or where one stands. However, there is a difference between Solanas and Diamond in their writing and thinking. Diamond writes about aspects of reality that render us speechless - whereas Solanas' response to 'the difficulty of reality' is to scream (cf. Ronell 2004, 2010).
} 


\section{THE GRAMMAR OF PATRIARCHY}

Solanas introduces us to a world of Men, Daddy's Girls and groovy females subverting the system:

Daddy's Girl, always tense and fearful, uncool, unanalytical, lacking objectivity, appraises Daddy, and thereafter other men, against a background of fear ("respect") and is not only unable to see the empty shell behind the façade, but accepts the definition of himself as superior, as a female, and of herself as inferior, as a male, which thanks to Daddy, she really is (Solanas 2004: 44).

On the surface, Solanas blames men; by nature (or is it quasi-nature?) they are passive, egoistic, parasitic beings who mar the world with their presence. As such beings, men cannot even face their own lack of security. Women are continuously created as bearers of these male characteristics. Men make woman passive, egoistic and dependent - because that is what he himself is, or makes himself to be, but cannot bear to be seen as. It is clear that 'male' is the primary concept, in that 'female' is everything 'male' is supposed to not be. "Being an incomplete female, the male spends his life attempting to complete himself, to become female" (Solanas 2004: 27). She paints a toxic dialectic of two sexes/genders, where the one exists as the dark secret of the other. Female passivity is male passivity, male passivity is a constant process of projecting his passivity onto others, constantly needing to be acknowledged and confirmed as the strong, independent Man. Alluding to this psychoanalytic thematic, Solanas describes how this mirroring leads to hollowness in everybody - to an empty life.

The female's individuality, which he is acutely aware of, but which he doesn't comprehend and isn't capable of relating to or grasping emotionally, frightens and upsets him and fills him with envy. So he denies it in her and proceeds to define everyone in terms of his or her function or use, assigning to himself, of course, the most important functions - doctor, president, scientist - therefore providing himself with an identity, if not individuality, and tries to convince himself and women (he's succeeded best at convincing women) that the female function is to bear and raise children and to relax, comfort and boost the ego of the male: that her function is such as to make her interchangeable with every other female (Solanas 2004: 46-7).

Man and Woman are figurations, expressing different perspectives, abstract models in a sense, not essentialist understandings or descriptions of gender - but descriptions of what essential understandings of gender do with us. In other words: how we turn ourselves into walking and talking essences.

\section{MALENESS, DADDY'S WORLD}

Solanas shows us what it means to understand the world through the concept of 'maleness' and everything entangled with it. Through the perspective of the male everything becomes distorted and infected. The logic of the male is expressed in terms of identity: in writing about Daddy's Girls, and the Great Man, Solanas targets the ways in which the existence of Man is self-deceptive. In his inability to face himself, he projects his own passivity onto women and takes comfort in the identity of being a man. She describes how the male is emotionally crippled, unable to relate to anyone, and only capable of negative feelings. His existence is ridden by guilt, shame, jealousy, contempt and insecurities. He is incapable of relating, he cannot have relations, and philosophically he presents us with universalism: "Unable to give of love or affection, the male gives money" (2004: 41).

The effect of fatherhood on males, specifically, is to make them 'Men', that is, highly defensive of all impulses to passivity, faggotry, and of desires to be female. Every boy wants to imitate his mother, be her, fuse with her, but Daddy forbids this; he is the mother; he gets to fuse with her. So he tells the boy, sometimes directly, sometimes indirectly, to not be a sissy, to act like a 'Man'. The boy, scared shitless of and 'respecting' his father, complies, and becomes just like Daddy, that model of 'Man'-hood, the allAmerican ideal - the well-behaved heterosexual dullard (Solanas 2004: 44).

Solanas shows us the conceptual surrounding of expressions such as 'be a man!' and 'don't be a sissy!'. She presents the muddle of gendered logics: a 'sissy' is taken as a faggot, and the faggot is a faggot because he is a woman, thus not a man. But women have to act like faggots to please and comfort men. Women are faggots, and faggots are women. Men are everything else - everything good, that is. These ways of talking are not only connected to questions of gender. A major point in The SCUM Manifesto is that concepts of gender cannot be isolated. That is why it is so difficult to see where the problems lie. Images of maleness and femininity are tied up in a shared human existence, in which gender is a part - as Nietzsche would say: a poisoning part, a part that turns the entire existence to shit. We have emphasised how Solanas actualises difficulties we face in the context of the everyday 
and our shared lives. Let us now give you an example of this kind of entanglement, and problematique from the context of our own lives - in this case, of a situation in which Sara is playing a board game with her family:

Sara: I am playing a board game with my family (my partner and our two kids) on a nice Saturday evening when we are all gathered together, I lose. No big deal really, but then my four-year-old son looks at me with spite and concludes loudly:

"Mummy lost because she has a pussy, I and Daddy won!"

I freeze.

I’ve brought a monster into this world.

Then I of course try to explain that girls can do the same things as boys, that boys can do the same things as girls, and that it has nothing to do with my pussy that I lost. He nods and says he understands, but I can see in his eyes that he's confused. As if I was claiming that blue is red or that tomorrow is today. Feminist questions do not only concern, in this case, a feminist (me) clinically studying how "socialisation is gendered". In this case it's only about me understanding that my child is learning to despise women.

Feminist theory is sometimes described as a 'tool box' for analysing how different categories (for example, misogyny, homophobia and racism) 'work' in relation to the structures power and oppression. But feminist theory also often leaves us, or the feminist critic, there. We are left with our concepts, our theories and descriptions of power relations but also with the anger and frustration we experience in facing them. Concepts and historicising gestures do not always help us face our anger and frustration. That is why it is so important to acknowledge that there is another aspect to the 'toolbox': our struggles with reality that are existential, personal, our own. In trying to sort out what is at stake here, let us think about the struggles of Elizabeth Costello. There is no struggle with reality when seeing the thing on your plate as food, as a piece of meat, but in describing what is on your plate as a dead animal, a corpse. The board-game example is about the same difficulty. The description expresses that something is wrong: a child is learning to despise women. It expresses fear and triggers memories; I (Sara) become the little girl-parent, unable to throw rocks properly and, of course, losing games. Sometimes, when we have presented this text at a conference, reading this example out loud, people in the audience have started laughing. Maybe they laugh because they pay attention to other aspects of the story ( $\mathrm{I}$ am, after all, describing my child as a monster). After the last sentence they stop. Silence. The room is filled with a sense of tension, awkwardness. They know that instead of food, they have been served a piece of dead cow, and they are left alone to figure out what the hell to do with it.

It is important to note that the connections Solanas draws are not theoretical, but moral and existential, and that the connections are bound up with the question: why the hell do people go on living these lives?

Trained from an early childhood in niceness, politeness and "dignity", in pandering to the male need to disguise his animalism, she obligingly reduces her own "conversation" to small talk, a bland, insipid avoidance of any topic beyond the utterly trivial - or is "educated", to "intellectual" discussion, that is, impersonal discoursing on irrelevant distractions - the Gross National Product, the Common Market, the influence of Rimbaud on symbolist painting. So adept is she at pandering that it eventually becomes second nature and she continues to pander to men even when in the company of other females only (Solanas 2004: 56)

The life of Man is dead. The entire world is trivialised. She depicts a world of endless contempt - not least contempt directed at oneself - hidden under a surface of 'progress', 'respectability' and 'ambition'. Maleness is bound up with rationality, political mastery and sovereignty, and reflected in the practices and discourses of philosophy and arts. Solanas targets ideologies of gender and the ways in which these shape our activities in our everyday lives; these ideologies are no less than life-hating dynamics of fear, contempt and 'dignity'. She especially targets the institutions (money, work, 'leisure', the family, the state etc.) that maintain the Man.

\section{KILLING IDEAS}

In many ways Solanas exposes, challenges and crushes contemporary ideas and ideologies of gender. As every reader of the manifesto knows, she talks about killing men - but she is really talking about killing a certain life form; ideas and ideologies that are poisonous to us - that distance us from reality and create unlivable lives. Solanas reminds us of the importance of eliminating things that make life shallow: e.g., Family, Reproduction, Money, etc. 
She doesn't put faith in development, because she doesn't believe in the society we have. New and 'better' arrangements for Big Daddy and Daddy's Girl are not the answer (cf. Solanas 2004: 76). It is not possible to fix things so that everything eventually will be alright.

Political and philosophical questions sometimes have a kind of awkward grammar. In expecting us to position ourselves and argue for or against a philosophical position or argument, the difficulty of these questions, the forms they often take in our lives, are avoided. Political questions are sometimes characterised by the fact that something has gone too far, and is impossible to restore; situations in which it is impossible to start from scratch. It might be akin to being confronted with a pile of nuclear waste and be expected to have a solution for what to do with it. Or, it is as in the example with the board game and with Costello. Sometimes the description itself does the philosophical work. It brings out a perspective. It is a point of departure for reflection (reflection is also affective), rather than a lifeless object to dissect or deconstruct. The state we are in when common sense, the conventional philosophical 'wisdom' no longer helps us. When philosophy is not love of wisdom, but rather 'combat' and internal struggle (Ronell 2010: 1, 27). The state of feeling unhinged, trying to look around, trying to understand what is conventionally understood as perfectly normal, something that needs no further attention, boys being boys, studying philosophy, normal life. Solanas and the Manifesto remind us of what it means to be unhinged, to lead an impossible life. The existential burden we sometimes experience when we face resistance, or feel the burden of power structures dragging us down, somewhere there in the margins (we scream).

In the lecture Can One Lead a Good Life in a Bad Life, Judith Butler (2012) discusses some of Adorno's remarks on morality. Butler points out that a wrong life cannot be lived right; if one wants to pursue the good life, one must then resist the bad life, and not forget that a good life is a life lived with others. One could say that the same question also bothers Solanas, who resists the destructive aspects of a life under a gendered system or ideology: the image of suburban happiness, of the small family unit having become 'independent'. This is also an important aspect of understanding the need for change, and the need for collapse that is raised within feminist philosophy, activism and academic work. For example, when de Beauvoir wrote her famous words - that one is not born a woman, but one becomes one - it wasn't a description only of the ways in which 'we' are socialised to become 'women'. Her descriptions in The Second Sex of various forms of femininity and the structures of otherness were also descriptions of something that needed to change.

Solanas writes from a tormented place of frustration, particularly in existential terms, of the difficulty and desperation of living in a world where one does not find one's feet. Still, she is familiar with it, she lives in it - it is no mystery to her. Here the similarities with the Adorno of the completely devastated Minima Moralia are striking. They both adapt the language of psychoanalysis for their own ends. Adorno writes:

If the psychoanalytic theory holds, that women perceive their physical constitution [Beschaffenheit] as the consequence of castration, then in their neurosis they intuit the truth. Those who feel themselves to be wounds when they bleed, know more about themselves than those who style themselves as flowers, because that's what their busband likes. The lie is not merely that nature is affirmed, where it is merely tolerated and built in, but that what passes for nature in civilization is according to its substance the most removed from everything natural, the pure turning of oneself into an object. The kind of femininity which calls upon the instincts, is invariably the one to which every woman must compel herself with all manner of violence - with masculine violence: the little women are little men” (Adorno 2005: \59, emphasis added).

Like Solanas, Adorno performs a cultural critique and shows us how personal, cultural, political and philosophical questions cannot be disconnected. Often when trying to make sense of people's different experiences and realities, one is easily led to think that in hurt and damaged descriptions, reality is blurred, less real. Inspired by Adorno, we want to challenge this idea. Adorno's description of the woman who has difficulties feeling like a flower, who feels like an open wound when she bleeds and who is the sane one, reminds us of SCUM. Both Adorno and Solanas have lost faith in humanity (Adorno is writing after the Holocaust). It also reminds us of what's at stake in the board game example that expresses an understanding, a fear, that a child is making Big Daddy's outlook on life his own. It's a sense of losing faith in order to keep the faith. Sometimes alienation, the feeling of losing one's mind, slipping, not being able to make sense of reality when it has become an ongoing nightmare, is a sane reaction (and the opposite would be self-deception?). Also think of Elizabeth Costello: it is hard to enjoy a cozy family dinner when a dead corpse from an industrialised slaughterhouse sits upon one's plate.

\section{'LIFE IS ABSURD' - THE INVENTION OF PHILOSOPHY}

When we first read The SCUM Manifesto, we were thrilled. For all its wounds and desperation, the Manifesto is also a text of revelation, of clarity, of dissipating phenomena that are revered. Instead of resentment, Solanas employs a brutal brand of humour when working with familiar figures of thought and common ways of talking. 
As Ronell states in her preface to the Manifesto: "Wounded and wounding, she comes out shooting, unsnapping all manner of discursive safety nets and cultural supports that have allowed violence to be absorbed." (Ronell 2004: 15). This should not be assigned as mere style; the brutal disclosure is an important dimension of the understanding Solanas offers. Fucking up is not only a matter of provocation - in the Manifesto, fucking up is a matter of survival. Even though the text contains humour, the humour never strays from or alleviates that sense of survival, of trying to imagine a society different from the constant state of being distracted from what truly matters in life. Men are chasing the perfect form of satisfaction, and women desperately try to deliver it to them. In this society we are rendered blasé; a social code is enforced that ensure blandness. Solanas describes a society of polite newspeak that turns baby talk into the language of businessmen and 'great thinkers'. One could say, then, that for Solanas, 'fucking up' is all about gaining clarity and making sense out of nonsense. But clarity is different from what is now lauded as great thinking and great art. On the topics of philosophy and religion Solanas writes:

The male's inability to relate to anybody or anything makes his life pointless and meaningless (the ultimate male insight is that life is absurd), so he invented philosophy and religion. Being empty, he looks outward, not only for guidance and control, but for salvation and for the meaning of life. Happiness being for him impossible on this earth, he invented Heaven (Solanas 2004: 52).

And of (male) philosophers she writes:

So they label the male condition the Human Condition, posit their nothingness problem, which horrifies them, as a philosophical dilemma, thereby giving stature to their animalism, grandiloquently label their nothingness their "Identity Problem", and proceed to prattle on pompously about the "Crisis of the Individual", the "Essence of Being", "Existence preceding Essence", "Existential Modes of Being", etc., etc."

A woman not only takes her identity and individuality for granted, but knows instinctively that the only wrong is to hurt others, and that the meaning of life is love (Solanas 2004: 53).

In Big Daddy-philosophy, Man is alone, he is an Island who 'values' and 'respects' others (who 'deserve' his respect), but can never fully relate or love anything, because he despises himself. As a perspective and as a starting point, this is infective (bad philosophy in bad life). Since Big Daddy turns everything into shit, Solanas cannot make his questions her own. No good philosophy springs from a bad question - 'bad' in the sense of parasitic, blood-sucker philosophy; the kind of thinking that glorifies the image of the rugged individual boldly facing the dread of absurdity and social alienation. Solanas is alone, but not in the same sense that Big Daddy is 'alone'. Again: she dreams of groovy females fucking up. But most importantly, Solanas does not consider 'Philosophical questions' to be real questions, but questions of the narcissistic Male Ego. The 'Identity Problem' is not a problem to her in a philosophical sense. What troubles her is what is expressed in and by the kind of 'Problem' identity is portrayed to be: a world view of self-aggrandisement, fear and the desire to disappear in the warm folds of the collective, while at the same time thinking of oneself as the Heroic Individual. Male philosophy is lonely, in contrast to communities in which thinking is done together with other people in an ongoing conversation and in which one believes that happiness lies outside oneself (cf. Solanas 2004: 53, 66, 75).

Solanas writes about groovy, thrill-seeking females who love instinctually. In a grammatical sense, groovy, thrillseeking females do not find life absurd - if they do, it's not in the same way as the Philosopher finds it. Through Solanas' perspective we see how this form of life of the Great Big Man and Daddy's Girls cannot be endured. Solanas writes:

But SCUM is too impatient to wait for the de-brainwashing of millions of assholes. Why should the swinging females continue to plod dismally along with the dull male ones? Why should the fates of the groovy and the creepy be intertwined? Why should the active and imaginative consult the passive and dull on social policy? Why should the independent be confined to the sewer along with the dependent who need Daddy to cling to? (2004: 71).

Here, Solanas can be and has been read as articulating a radical feminist viewpoint, questioning the culture that teaches women to please and serve others. Similarly as for de Beauvoir, what is at stake is freedom. 


\section{IS SOLANAS A PHILOSOPHER?}

As mentioned earlier, few have read Solanas as a philosopher. Is she one?

Solanas in many ways addresses central questions in feminist philosophy. The SCUM Manifesto is a critique of institutions, of authority. And Solanas is impatient. She doesn't have time or patience for philosophy. So, what becomes of the philosopher in Solanas? Examining this issue we might get a glimpse of how questions about what is philosophy and what is not become political, questions of ideology. First, it is clear that Solanas despises 'Philosophers'. She talks about 'them', refusing the term 'us' and this should be respected. She is also not a 'feminist'. That too should be respected. Why this refusal? Solanas is quite clear about the fact that the liberal feminists are wrong.

'Daddy's Girls' have no place in the new world order she envisions. What Solanas brings to the forefront is that to argue or debate about 'Philosophy' or 'Art' is to miss the point. These are all activities related to values of the Great Man. Art cannot be considered without its gendered nature; philosophy is a male activity, one of selfdeception reflecting the existence of constant lack in the male (Solanas, as we have seen, reverses the psychoanalytic account of woman as lack). But Solanas doesn't talk about lack here to advance a 'theory of the subject'. She talks about hollowness: life is squeezed out of us by living in a male world. Bad faith (Sartre - the overrated windbag) ${ }^{10}$ could be another term. It is evident that she despises identity and destructive forms of belonging and collectivity.

Identity is destructive when we cling on, to belong to something, instead of facing our own lives. There is comfort in the convenience of being one of the guys/girls/moms/Finns. The power and the dangers of collectivity, and identity within it, is shown in the failures of belonging, in exclusion or alienation. Solanas suggests alienation as a way out, together with thrill-seeking females who loot the system.

Not making 'Philosophical problems' her own is a political statement, but also a comment on the patriarchal grammar of 'Philosophy': 'Philosophy' is not made by groovy females, clowns or prostitutes - subjects whom the Philosopher's rumination does not even take into account.

So when thinking about whether Solanas should be considered a philosopher or not, the question is not only about Solanas. It is also about what kind of questions one finds important. Sometimes they are political ones. For Solanas, gender - being male or female - is a way of losing one's individuality, being reduced to an identity (a walking essence $)^{11}$. This could also be interpreted as taking refuge in norms, fleeing into collective forms of being (Heideggerian herd mentality). But questions of morality, and of taking a moral stance, cannot be collective. These are issues one has to figure out for oneself.

To conclude our discussion of Solanas and philosophy, we want to consider an example that Avital Ronell (2010) gives us about her coming to philosophy. The example serves here as a contrast we wish to illuminate, between different perspectives on the power of normativity within academia, and the desire for radicalism that spurs so many critical thinkers.

\section{CONCLUSION: MISFITS, SOLANAS, RONELL \& GADAMER}

In thinking about the problem of 'others' in philosophy, or what is sometimes called 'the woman problem in philosophy', as one of the outsiders within, an example is perhaps useful. Avital Ronell (2010: 27) talks about her coming to philosophy through giving an account of when she attended a colloquium in Heidelberg as something of a rogue: a young, punk, critical philosopher who boozed with Gadamer, already an older man, and how they behaved as misfits, 'we almost danced on the tables', behaving 'scandalously'. Later however, when they take a walk, Gadamer encourages the 25-year-old Avital to seek out a master:

We kept on walking and he said: 'You know Avital, to be a real thinker one day, you have to find a master. There is no other way, no possible route. You have to attach yourself to a master and do the painful work of apprenticeship. To go on otherwise is an illusion, and it isn't real philosophical work.' (Ronell 2010: 27)

Of course Avital is revolted by his words, but ... she goes to France and studies with Derrida for two years, indeed finding a master. Ronell speaks of feeling misplaced in philosophy and searching for place in unconventional spaces and dark alleys. She too finds traces of philosophy in Solanas. However, the question remains why the figure

\footnotetext{
${ }^{10}$ Solanas called de Beauvoir and Sartre overrated windbags - another example of how she views philosophy and philosophers (Heller 2001, quoted in Ronell 2004: 6).

${ }^{11}$ Here it is important to note that when Solanas writes about gender as male or female, she is describing how a particular gendered logic works; this should not be read as endorsing a binary understanding of gender (excluding non-binary gender identification for example).
} 
of a 'Master' is so pertinent? What if the Master doesn't want what is best for one? Must one be trained in misogyny in order to recognise and criticise it? What a waste of time!

Of course, if we take the example further and imagine being a young woman and a misfit and attending a colloquium on philosophy in Heidelberg where nobody spoke to you, or wanted to drink with you or talk philosophy with you, where you would not be one of them, or even part of the cool outcasts, the example becomes something different. Philosophy that emphasises conversation and dialogue suddenly becomes something else. When all there is, is silence. This is an example where the destructiveness of institutionalised philosophy, its inbuilt hierarchies and forms of violence really show, and where the outcome is not 'productive'. There is a certain coolness and romanticised picture of philosophical dialogue in Ronell's example. Who would not want to drink with Gadamer; and, after all, she studied and taught with Derrida. But it also reminds us that for Solanas thinking like this isn't an option, or perhaps her perspective mocks discussions of choice or option. As we said: for her, it's about trying to survive in a patriarchal society. Solanas doesn't put herself in a position where the philosopher can refuse her. She values herself and her life more than that.

In the article Out of Bounds: Philosophy in an Age of Transition, Judith Butler and Rosi Braidotti (2010) write about their experiences of coming to philosophy, a discipline that in many ways has resisted (women) and critical theories. They write about how being critical thinkers and philosophers meant asking questions such as:

how to connect the practice of thinking to larger social and ethical concerns and how to resist the negative and oppressive forces of the present [...] what philosophy is all about and how it can help us lead politically useful, socially productive and morally adequate lives? (Butler \& Braidotti 2010: 310).

Solanas, Butler and Adorno are all aware of the difficulties that might arise when exploring philosophical questions of 'the good life'. 'The good life' that Solanas shows us is wrapped up in ideology - money, health and success that shapes our contemporary culture through a western and patriarchal ideology that has gained the status of being 'good in itself. Solanas' approach to ideology is interesting, since the danger of ideology is described in her understanding of 'life' ('an utter bore').

In revealing 'the grammar of patriarchy' through a description of the corruptness of gender as identity, Solanas describes a world of ordinary and normalised violence that takes the form of institutions (money, the government) and ideas about the good life (decency, compliance, 'the male outsider'). She spells out the connections between gender, identity, destruction and maleness. The Manifesto focuses on the urgency we sometimes feel when faced with moral, political and existential difficulties. Performing a cultural critique of her own, Solanas reveals the corruptness of gender relations. She shows us how what seems perfectly ordinary and good (a comfortable family life, a busy job, intellectual pursuits like Art or Philosophy) is actually deeply troubling. In a sense, Solanas' Manifesto doesn't engage with theory, epistemology or ontology at all. Thinking about the text in relation to the theme of this issue, one could say that the question of 'epistemic habits' does not concern Solanas at all. She is not within that discourse - she doesn't care. What she cares about is no less than a life of love and compassion.

Both Butler (2012) and Solanas remind us that life both is and is not one's own. This is where Solanas, although something of an anti-social philosopher, becomes liberating. In presenting us with fuck-up crews and groovy females she also reminds us that sometimes dropping out is not the answer: fucking up is. Most women have already dropped out; they were never in.

In her Manifesto, we claim, Solanas examines the patriarchal grammar of Life, where Big Daddy clings to a pair of tits and Daddy's Girl clings to Big Daddy - a life that Solanas rejects, describing it as shallow and self-deceptive. This exclusion works on many levels; being true to oneself might be the only way to go, but it is also a lonely path. Feeling the burden of a grim society. She still wants to lead a meaningful life. Solanas challenges normative and damaging ideas: for her, critique is not about coming up with new concepts. When Big Daddy makes money and finds it important to reproduce (live forever?), Solanas says that the meaning of life is love. Or that it should be, and that something has to change. Ronell describes Solanas' style and voice as a scream - a scream that cuts through. By rejecting the patriarchal grammar, Solanas makes new spaces, or simply cracks, where we can talk about what's really important. In her own way, Solanas shows us what a desire for change looks like and how a desire for change in one's own life is bound up with change in other people's lives and attitudes. Screaming is an acute call for change, and it is in this spirit that we find the value of feminist critique, in a life that both is and is not one's own. 


\section{REFERENCES}

Adorno T. (1951/2005). Minima Moralia: Reflections from a Damaged Life. New York: Verso.

Anderson, A. (2006). The Way We Argue Now. A Study in the Cultures of Theory. New Jersey: Princeton University Press.

Butler, J. (2012). Can one lead a good life in a bad life? Journal of Radical Pbilosophy, (176)9, pp. 9-18.

Braidotti, R. and Butler, J. (2013). Out of bounds: Philosophy in an age of transition. In: R. Braidotti, ed., The History of Continental Pbilosophy Volume 7 - After Poststructuralism: Transitionsand Transformations (pp. 307-335). Durham: Acumen.

Diamond, C. (2008). The difficulty of philosophy and the difficulty of reality. In: S. Cavell, C. Diamond, J. McDowell, I. Hacking and C. Wolfe., eds., Philosophy and Animal Life. (pp. 43-90) New York: Columbia University Press.

Fahs, B. (2008). The Radical Possibilities of Valerie Solanas. Feminist Studies, 34(3), pp. 591-617.

Fahs. B (2014). The Defiant Life of the Woman Who Wrote SCUM (and shot Andy Warbol). New York: The Feminist Press at the City of New York University.

Fahs, B. (2016). Spitfire and sass: Valerie Solanas's “A Young Girl's Primer" and the creative possibilities of a survival self. WSQ: Women's Studies Quarterly, 44(1-2), pp. 255-267.

Felski, R. (2015). The Limits of Critique. Chicago and London: University of Chicago Press.

Felski, R. and Anker, S. (2017) Introduction. In: R. Felski and S. Anker, eds., Critique and Postcritique (pp.1-28). Durham and London: Duke University Press.

Love, H. (2014). Doing Being Deviant: Deviance studies, Description and the Queer Ordinary. Differences: A Journal of Feminist Cultural Studies, (26)1, pp. 74-95.

Love, H., Best, S. and Marcus, S. (2016) Building a better description. Representations, (13), pp. 1-21.

McBean, S. (2016). The feminist manifesto. Valerie Solanas and SCUM. In: S. McBean, Feminism's Queer Potentialities (pp.97-121). New York and London: Routledge.

Moi, T. (2009). They Practice Their Trades in Different Worlds. New Literary History, (40)4, pp. 801-834.

Moi, T. (2017). The Revolution of the Ordinary. Chicago and London: University of Chicago Press.

Nordling, B. (2013). Describing a Revolution. The Pbilosopby of Animal Ethics, unpublished MA thesis in Philosophy, Åbo: Åbo Akademi University.

Ronell, A. (2004). The deviant payback: The aims of Valerie Solanas, Introduction. In: V. Solanas, ed., The SCUM Manifesto (pp. 1-34). New York and London: Verso Books.

Ronell, A. (2010). Fighting Theory. Avital Ronell in Conversation with Anne Dufourmantelle. Urbana, Chicago and Springfield: University of Illinois Press.

Rowe, D.D. (2011). I Should've Done Target Practice: Why Valerie Solanas Missed. Qualitative Inquiry, (17)2, pp. 130-133.

Rowe, D.D. (2013). The (dis)appearance of Up Your Ass: Valerie Solanas as abject revolutionary. Rethinking History: A Journal of Theory and Practice, (17)1, pp. 74-81.

Rowe, D.D. (2014). Performative (re)Writing: Performative writing and the politics of scribble. Women and Language, (36)2, pp. 107-113.

Sedgwick, E.K. (2003). Touching Feeling: Affect, Pedagogy, Performativity. Durham: Duke University Press.

Rosenberg, R. (2010). Still Angry After All These Years or Valerie Solanas Under Your Skin. Theatre Journal, (62)4, pp. 529-534.

Solanas, V. (2004). The SCUM Manifesto. New York \& London: Verso Books.

Third, A. (2006). 'Shooting from the hip': Valerie Solanas, SCUM and the apocalyptic politics of radical feminism. Hecate: An Interdisciplinary Journal of Women's Liberation, 32(2), pp. 104-132.

Wittgenstein, L. (1997). Philosophical Investigations, transl. G.E.M Anscombe. Oxford: Blackwell.

Citation: Peltonen, S., Lindman, M. and Nyman, S. (2017). Perceiving Shit as Shit: On the Grammar of Patriarchy in Solanas' SCUM Manifesto. Feminist Encounters: A Journal of Critical Studies in Culture and Politics, 1(1), 09. https://doi.org/10.20897/femenc.201709

Copyright (C) 2017 by Author/s and Licensed by Lectito BV, Netherlands. This is an open access article distributed under the Creative Commons Attribution License which permits unrestricted use, distribution, and reproduction in any medium, provided the original work is properly cited. 